\title{
Urbanization in Developing Countries
}

\author{
Vernon Henderson
}

The rapid urbanization in many developing countries over the past half century seems to have been accompanied by excessively high levels of concentration of the urban population in very large cities. Some degree of urban concentration may be desirable initially to reduce inter-and intraregional infrastructure expenditures. But in a mature system of cities, economic activity is more spread out. Standardized manufacturing production tends to be deconcentrated into smaller and medium-size metropolitan areas, whereas production in large metropolitan areas focuses on services, research and development, and nonstandardized manufacturing. The costs of excessive concentration (traffic accidents, health costs from exposure to high levels of air and water pollution, and time lost to long commutes) stem from the large size of megacities and underdeveloped institutions and human resources for urban planning and management. Alleviating excessively high urban concentration requires investments in interregional transport and telecommunications to facilitate deconcentration of industry. It also requires fiscal deconcentration, so that interior cities can raise the fiscal resources and provide the services needed to compete with primate cities for industry and population.

A high degree of concentration - the share of large metropolitan areas in total urban population-characterizes the rapid urbanization in many developing countries today. That concentration is also reflected in urban primacy - the share of the largest city in national urban population. And it involves megacities of unparalleled size, presenting major problems in health and quality of life, international industrial competitiveness, management and institution building, social cohesion, and stability. What has fostered such high degrees of urban concentration in developing countries, a pattern not seen in many developed areas? Has concentration become overconcentration? If so, what are the key institutional and policy issues for alleviating overconcentration and promoting more orderly development and urbanization?

Developing countries today face greater urbanization challenges than developed countries faced. Developed countries urbanized at a comparatively leisurely pace. The United States was 40 percent urbanized in 1990, 70 percent in 1960, and 75+ percent in 1990. This gradual pace is in marked contrast with that in many developing countries. For example, the Republic of Korea was 40 percent urbanized in 1970 and 
78 percent urbanized by 1990 . What took the United States 90 years to accomplish took Korea 20 years and Brazil 30 years.

That gradual pace, combined with relatively high gross domestic product (GDP) and education per capita at the beginning of the century, allowed time for the development of the political and economic institutions and market instruments essential for an efficient form of urbanization and a reasonable quality of urban life. These included mechanisms for the internal governance and financing of cities, intergovernmental arrangements, regulatory and financial instruments for intercity communications and transport networks, a civil service with technical expertise in urban and regional planning and service provision, and institutions for efficient functioning of national and local land markets. For rapidly urbanizing developing countries, the societal learning required to adapt rural institutions and governance to urban ones became a crash course, leaving little room for timely experimentation and adjustment.

This article looks at the form urbanization takes - the degree of concentration within a typical institutional and policy context — rather than at urbanization itself - the share of the national population residing in urban areas. It looks first at the basic theoretical concepts and empirical patterns governing a mature urbanized economy. What does a system of cities look like in a medium- or high-income country with well-developed urban institutions and governance and well-functioning land and capital markets? That provides a benchmark. In looking at the urbanization process in developing countries, the article then explores why urban concentration sometimes increases strongly in developing countries. When is concentration excessive, and what are the costs of excessive concentration? What do inter- and intracountry data show? The final section looks at the policies and institutions that help shape urbanization, in particular economic liberalization, fiscal deconcentration, intercity infrastructure investments, globalization, and urban institutions. What are the key elements for achieving reasonably efficient urbanization that benefits most segments of the national population?

\section{Cities in a Mature Urban System}

Urbanization is a natural part of development. Labor-saving technologies in agriculture and shifts in the composition of national output away from agriculture release labor for industrialization. Industrialization occurs disproportionately in urban areas because of opportunities to exploit scale economies of local agglomeration. About 70 percent of the cross-country variation in urbanization is explained by variations in GDP per capita. Figure 1 illustrates the log-linear relationship for $1990 .{ }^{1}$

It helps to have a framework to examine the link between urbanization and development and to deal with the fundamentals of urban allocation in a country. A framework can help structure thinking about the productivity of cities - is big good? - and to understand phenomena such as product cycles and new information technologies. 
Figure 1. Urbanization and Income

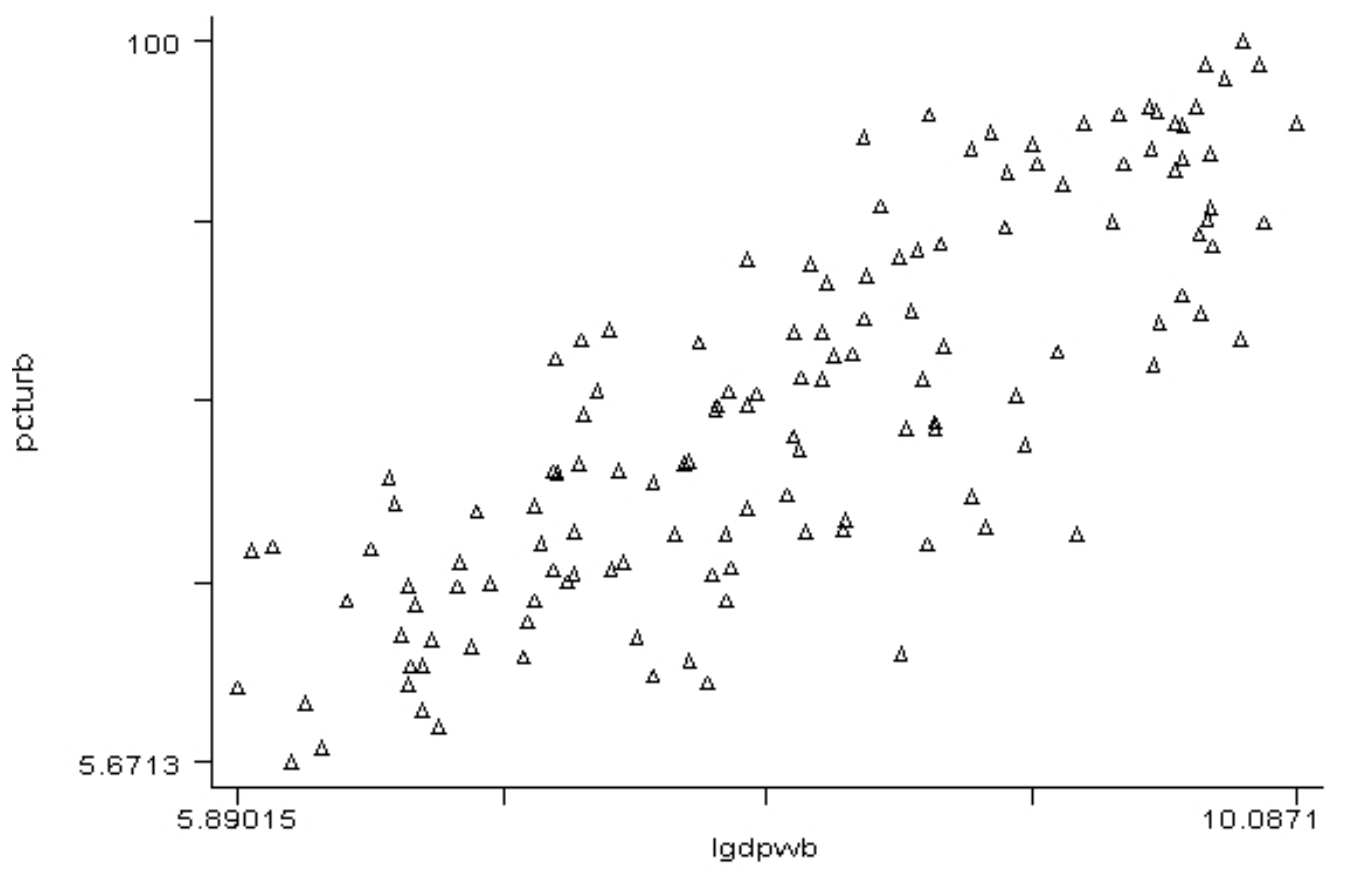

It can help answer questions about why cities form, what determines or limits their size at various points in time, why they grow, how they specialize in different types of production, and what determines the size distribution of cities in a country. This discussion sets the stage for examining the role of institutions and infrastructure investments in urban development and for analyzing the effects of economic liberalizations, globalization, and political decentralization on urbanization.

\section{Why Urbanization: The Economics of Agglomeration}

Economic activity agglomerates in cities because of local external economies of scale in production-a plant's productivity is enhanced if other plants are located nearby. Why is this? Urban models of the micro-foundations of urban externalities follow Alfred Marshall's (1890) description of spillover benefits for a plant from others in the neighborhood-information spillovers about technology, suppliers, purchasers, and market conditions (Fujita and Ogawa 1982); scope for local intraindustry specialization of plants in specific activities (Becker and Henderson 2000); increased diversity of local suppliers to local export producers (Dixit and Stiglitz 1977; AbdelRahman and Fujita 1990); and search for and matching improvements between workers and firms in local labor markets (Helsley and Strange 1990). In addition, 
the proximity of buyers and sellers reduces transport costs of trade (Krugman 1991) and search costs in retailing (Caplin and Leahy 1998).

Research suggests that plants producing standardized products (textiles, steel, ceramics, food processing) learn mostly from other plants in the same industry locally, so that they benefit primarily from what are called localization economies, as first documented by Hoover (1948) for industries such as footwear in the United States. Recent econometric evidence for Korea shows similar benefits (box 1). In contrast, urbanization economies, deriving from the overall local scale of a metropolitan area, benefit plants engaged in nonstandardized production (special-order machinery, high-fashion ap-

Box 1. Evidence on Agglomeration Economies

Econometric work has quantified the degree of local external economies, distinguishing between localization and urbanization economies. Industries subject to localization economies, which depend on local own-industry scale, tend to locate in small and medium-size specialized cities. Industries more subject to urbanization economies are drawn to large diverse metropolitan areas. For Japan, Nakamura (1985) found strong evidence of localization economies in iron and steel, nonferrous metals, nonelectrical machinery, transport equipment, and precision instruments and evidence of urbanization economies for such industries as publishing and furniture. For Indonesia, Henderson and Kuncoro (1996) found strong localization economies for apparel (including textiles), nonmetallic minerals, machinery (including transport equipment and electrical machinery), and miscellaneous manufacturing (toys, jewelry, musical instruments) and evidence of strong urbanization ecnomies for wood, furniture, publishing, and apparel. Results for the United States are similar (Henderson 1988).

For the Republic of Korea, Henderson, Lee, and Lee (2001) estimate urban scale economies using city industry data for 1983, 1989, and 1991-93. They examine the determinants of value added per production worker across cities by industry, controlling for capital per worker and accounting for time, city, and subindustry fixed effects. Their results on the magnitude of localization economies are reported in the table below. A coefficient of 0.06-0.08 means that a 1 percent increase in local own-industry employment results in a $0.06-0.08$ percent increase in plant output. So a plant in a city with 1,000 workers in other firms in the same industry would, without changing its own inputs, increase its output by over 70 percent by moving to another city with 10,000 workers in the same industry. That is a big incentive. Henderson, Lee, and Lee (2001) show that the ranking of the magnitude of externalities exactly matches the ranking of industries by extent of spatial concentration across cities. So heavy and transport industries tend to be concentrated in a few highly specialized cities, whereas traditional industries with low scale externalities are more dispersed.

In searching for urbanization economies, Henderson, Lee, and Lee (2001) found that measures of metropolitan scale had no effect on productivity in any industry (see table 1). Drawing on Jacobs (1969) and Glaeser and others (1992), Henderson, Lee, and Lee created a diversity measure for each city based on the sum over all manufacturing industries of the squared deviations in each industry's share of local employment from its share of national employment. In perfectly diverse cities employment shares match national shares. In high-tech industries (only), Henderson, Lee, and Lee (2001) find strong significant diversity economies, where a one-standard-deviation increase in diversity increases productivity by 60 percent. This accords with the intuition that the bright lights of diverse large metropolitan areas, with cross-industry fertilization of ideas, are important for evolving high-tech industries but not standard ones. 


\begin{tabular}{lcc}
\hline Table 1. Magnitude of External Economies of Scale for the Republic of Korea \\
\hline & $\begin{array}{c}\text { Localization } \\
\text { economies } \\
\text { (elasticity) }\end{array}$ & $\begin{array}{c}\text { Urbanization economies } \\
\text { (percentage increase in } \\
\text { productivity for one standard } \\
\text { deviation increase in diversity) }\end{array}$ \\
$\begin{array}{l}\text { Industry } \\
\begin{array}{l}\text { Traditional (food, textile, apparel, wood and paper } \\
\text { products and furniture) }\end{array}\end{array}$ & $0.021^{*}$ & $\mathrm{NA}$ \\
$\begin{array}{l}\text { Heavy (basic and fabricated metals, chemicals, } \\
\text { and plastics) }\end{array}$ & $0.082^{*}$ & $\mathrm{NA}$ \\
$\begin{array}{l}\text { Transport } \\
\text { Machinery and electrical machinery }\end{array}$ & $0.096^{*}$ \\
$\begin{array}{l}\text { High tech (computers, communication, television, } \\
\text { radio and scientific instruments) }\end{array}$ & $0.053^{*}$ & $\mathrm{NA}$ \\
\hline * Significant at the 5 percent level. & $0.056^{*}$ & $0.599^{*}$ \\
$\quad$ Source: Henderson, Lee, and Lee (2001). & & \\
\hline
\end{tabular}

parel, entertainment services, publishing), firms in interactive services with centralized markets (certain financial services, including stock and commodity markets), and high-tech firms in research and development (R\&D) and new products (electronics, software development) (Jacobs 1969). For example, plants engaged in product development need to get ideas and specialized employees from beyond their own industry by interacting with the scientific consulting industry, universities, the software industry, a diversity of suppliers - whatever tweaks the inventive process. They also need large local markets to test products and ideas locally and to get immediate feedback.

There may also be dynamic components to externalities. One is local knowledge accumulation (Rauch 1993), as in endogenous growth models (Romer 1986). Black and Henderson (1999) develop an urban growth model that suggests city sizes will grow over time, as local human capital development enhances economies of agglomeration. They document the strong empirical relation between human capital accumulation in individual cities and growth of city size.

Local knowledge accumulation implies that history matters. Cities with a history of employment in a particular industry will have built up a stock of local "trade secrets," which makes locating there much more attractive than in cities with no experience in the product. This presents an obstacle that newly industrializing cities have to overcome if they are to attract such an industry, although there is debate about the strength of this force (Holmes 1997; Rauch 1993; Glaeser and others 1992; Henderson, Kuncoro, and Turner 1995).

\section{Factors Limiting City Sizes over Time}

Although bigger cities offer higher productivity because of scale economies, residents of bigger cities are burdened with higher costs of living-for housing, food, public 
utilities, commuting, and so on (Muth 1969; Fujita and Ogawa 1982). In reviewing evidence on Latin America (Thomas 1980) and the United States, Henderson (1988) finds a doubling or more of costs of living in moving from a small city to a large metropolitan area. Rousseau (1995) calculates that living costs in Paris are 89-94 percent higher than the average for the rest of France. Richardson (1987) estimates that the marginal investment cost (including utility, public service, and housing costs) of absorbing an extra family in average urban areas of Bangladesh, Egypt, Indonesia, and Pakistan is three times that in rural areas - higher still for the primate city of a country.

In a market economy, city size reflects a tradeoff between the scale productivity benefits of local employment growth and the cost-of-living increments of local population growth. Improvements in commuting technology, which reduce local costs of living, and local knowledge accumulation, which accentuates scale economies, suggest that efficient city sizes increase over time. As commuting technology continues to improve and human capital investments rise in developing countries, the sizes of cities may continue to increase well into the 21st century, just as they did throughout much of the 20th century. At the same time, national population growth means that the number of cities may need to grow to accommodate population increases. Generally, both the size and number of cities have grown with national population growth in most countries over the past century.

\section{Urban Specialization, Diversification, and Productivity}

Most employment in a city (55-60 percent, often more) is engaged in nontraded goods production, such as housing, local retailing, local services, and local government. But as a result of the factors already discussed, mature medium-size and smaller cities will be somewhat specialized in the products and to some extent the services they produce for export (to other cities or abroad). Why is this? For products experiencing localization economies, cities specialize because adding a different industry does not help own-industry productivity, though it causes the cost of living to escalate. Such products include primary metals, pulp and paper, textiles, and machinery. Some of these products involve natural resource use and weight reduction in production, suggesting hinterland location. Specialization also extends to the service sector for market and transport node towns, state government and education centers, and agricultural services towns, as well as certain areas of health, recreation, and standardized business services.

Theory and evidence suggest that the size of specialization cities is positively related to the degree of localization economies of the good in which the city specializes. So steel and auto cities tend to be larger than textile cities and traditional service centers, which in turn are larger than pulp and paper and food-processing cities. As reported in Henderson (1988), this phenomenon of specialization has been studied for Brazil, India, Korea, and the United States (see box 2), among other countries. 
Box 2. Specialization among U.S. Cities

Bergsman, Greenston, and Healy (1972); Henderson (1988); and Black and Henderson (1998) use cluster analysis to classify cities by production patterns. Black and Henderson distinguish 55 city types, or clusters, based on 80 industrial categories covering all private employment in the United States in 1990. Production patterns of cities differ significantly across city types. Average size and educational composition also tend to vary by city type. They divide the 55 city types into eight broad categories: clothing and food (49 cities); wood products (14 cities); electronics (20 cities); heavy manufacturing (48 cities); oil and chemicals ( 19 cities); national and regional market centers ( 52 cities); health, hotel, state government, and recreation services (72 cities); and business, finance, education, and transport services (44 cities).

Out of 318 total cities, 35 focus on health services; these cities average 220,000 people. There are 6 highly specialized food processing cities and 13 pulp and paper and lumber cities, both averaging about 165,000 people. There are three highly specialized primary metals cities and nine former primary metals centers whose production composition is changing, both averaging 260,000-290,000 people. There are two highly specialized insurance cities averaging 627,000 and three recreation centers (Reno, Las Vegas, and Cape May) averaging 440,000. All the smaller types of manufacturing cities contain industries subject primarily to localization economies (see box 1). At the other extreme are large market centers - nine with traditional mixed industrial bases (wholesale, transport, and business services) and averaging 2.7 million people, seven with diverse modern services plus some manufacturing (health, education, engineering and management) and averaging 2.4 million people, and eight with newer mixed industrial bases (high-tech and engineering and management) averaging 1.4 million people.

Medium-size cities (under 750,000 people) play a key role in standardized manufacturing. In 1992 they accounted for 34 percent of the population of all U.S. metropolitan areas and 35 percent of manufacturing employment. They accounted for 44-54 percent of all employment in food, textiles, pulp and paper, wood products, petroleum, nonmetallic minerals, and primary metals industries. Medium-size cities are underrepresented (under 27 percent) in high-tech instruments and headquarters activity, activities subject to urbanization economies. In contrast, certain services cluster in large metropolitan areas. Though the primate cities of New York, Chicago, and Los Angeles have about 12 percent of the national population, they account for 40 percent of investment security services, 19 percent of banking services, 20 percent of holding and other investment services, and 19 percent of legal services.

City size and diversity are closely related. The normalized Hirschman-Herfindahl index of lack of diversity - the sum over 20 manufacturing industries of squared deviations of each subindustry's local share in manufacturing employment from its national share- has a sharp negative slope declining from an average of about 0.15 for the smallest cities (with a maximum observed value of 0.36 ) to almost zero for the largest cities (with an observed minimum of 0.0090) (based on an ordinary least squares regression of $g_{j}=0.4868-0.03119 \log$ of population $j$, where the standard error on the slope coefficient is 0.00381 , the number of observations $=317$, and $R^{2}=0.18$. 
However, many products require a diversified and hence large local environment to thrive. These include high-tech products, R\&D, high-fashion apparel, publishing, special-order machinery, financial services, company headquarters, and such business services as upscale advertising and placement services. Large metropolitan areas produce these products, but there is also relative specialization-some emphasize financial and international export market services, and others may emphasize hightech environments. But it is even more complicated than that. For example, diverse metropolitan areas are rich in large social networks, so they can become migration points, attracting migrants from the hinterlands especially in times of crisis, such as famine and civil unrest. These low skill-low wage migrants are an attractive labor pool for producers such as apparel manufacturers, who want both big local product markets and cheap labor.

Across the range of products and city types, the relative size distribution of cities is fairly stable over time (see Becker, Williamson, and Mills 1992 on India and Eaton and Eckstein 1997 on France and Japan). Big and small cities coexist and grow in population size in parallel, keeping the same relative size and offering residents similar standards of living. For example, both wages and costs of living differ by more than 100 percent in a city of 50,000 people and a metropolitan area of 5 million people, so real incomes are equal in both types of cities.

A plant seeking to locate in the bigger city must be able to afford wages that are twice as high, as well as high rents and public service taxes. To remain competitive, the plant must enjoy correspondingly larger output per worker. Rousseau (1995) estimates that productivity for the types of firms located in Paris is 240 percent higher than in the rest of France, but wage, tax, and rent differentials raise costs 245 percent. Most industries cannot afford these costs because they do not experience large enough productivity differentials, and so they locate outside Paris. Experience has been similar for the types of industries found in specialized medium-size and smaller U.S. cities and those subject to localization economies in Korea (see boxes 1 and 2).

Policymakers tend to focus on the greater output per worker in larger cities and ignore the higher opportunity costs of labor and land, creating a policy bias toward locating heavy, often polluting industries in larger cities. Traditional policy toward state-owned industry in China clearly demonstrates this bias: plants in big cities received favored access to the newest technology, best managers, appropriate funding, and export-import licenses. Shanghai's 1981 share of national industrial output (especially in heavy primary metals and machinery) was several times the share in New York or Chicago in 1914 (early period of U.S. industrialization and urbanization) and in 1977 (Henderson 1988), despite Shanghai's smaller relative share of national urban population. It is not surprising that many township industries today outcompete many state industries in Shanghai. They are not burdened with high costs of housing and feeding mega-city workers. 


\section{Product Cycles, Plant Cycles, and the Informal Sector}

For new products or plants, development appears to be accelerated by location in large metropolitan areas, in centers of information exchange (see box 3). New plants, which by definition are inexperienced, improve their chances of surviving by locating in an environment rich with external information about technology, suppliers, and markets. If these plants learn, grow, mature, and become more self-sufficient in information, they can move further out to satellite towns, where land and wage costs are lower.

New plants, especially smaller, informal sector plants, also play a key role in fostering local productive environments. In the Silicon Valley computer-electronics center around San José, California, most plants are small—in the informal, less regulated sector. In high-tech industries, small plants that rapidly appear, die, or split off play a key role in innovation, representing new ideas and ventures. They also play an important role in traditional industries by filling special orders and supplying key components to large-scale plants in the formal sector. Their role in developing countries is no different. For example, Mukherjee's (1990) work on Calcutta shows that the informal sector is a vibrant, productive sector that interacts strongly with the formal sector, meeting specific demands for components and repairs (see also Banerjee 1985).

The story for products is similar. Radio, television, and personal computer technology has typically developed in intense, usually metropolitan environments, such

Box 3. Product Cycles and Stages

Plant Cycles from the Seoul Metropolitan Area

Central cities are viewed as incubators for new plants. Once surviving plants mature and have established lines of communications, many decentralize to suburbs or more distant satellite cities. Table 2 shows patterns for the greater Seoul metropolitan area. In the early 1980, new plants outnumbered relocators 5.5 to 1 in the central business district but made up just 60 percent of the number of relocators in satellite cities. So new plants locate mostly in the core and then, if successful, relocate later to the suburbs. Among relocators, bigger plants move furthest, perhaps because they are less dependent on outside information and more concerned about wage and land costs.

Product Cycles for Japanese Electronic Firms

Fujita and Ishii (1994) examine the plant location patterns of the nine major Japanese electronic firms as of the early 1990s. They divide plants hierarchically into headquarter units, basic R\&D, developmental R\&D, trial production, and mass production. At the top are the most sophisticated, information-driven activities, with all information coming from the top down within the corporation.

A strict locational hierarchicy accompanies this hierarchy of activities. Within Japan, basic R\&D plants all go to major metropolitan areas, mostly Tokyo (see table 3). Mass production plants are mostly outside metropolitan areas, and those in metropolitan areas are in suburbs, not the central city (in contrast to headquarters and basic R\&D). Similarly, outside Japan, more sophisticated activities are located in the industrialized nations, whereas mass production of standardized parts, components, and products is located in the Association of Southeast Asian countries, China, and India. 


\begin{tabular}{|c|c|c|c|c|c|}
\hline & \multirow{2}{*}{$\begin{array}{l}\text { Ratio of new } \\
\text { plants to } \\
\text { relocators }\end{array}$} & \multirow[b]{2}{*}{$\begin{array}{l}\text { Location } \\
\text { distance }\end{array}$} & \multicolumn{3}{|c|}{$\begin{array}{c}\text { Distance of relocators } \\
\text { (percent of plants for each employment } \\
\text { category by distance moved) }\end{array}$} \\
\hline & & & $\begin{array}{c}1-25 \\
\text { workers }\end{array}$ & $\begin{array}{l}25-99 \\
\text { workers }\end{array}$ & $\begin{array}{c}100+ \\
\text { workers }\end{array}$ \\
\hline Central business district & 5.5 & $1-5 \mathrm{~km}$ & 30 & 13 & 3 \\
\hline $\begin{array}{l}\text { Metropolita area and } \\
\text { suburban rings }\end{array}$ & 2.6 & $6-35 \mathrm{~km}$ & 43 & 42 & 39 \\
\hline Satellite cities & 0.6 & $35+\mathrm{km}$ & $\begin{array}{r}27 \\
100\end{array}$ & $\begin{array}{r}45 \\
100\end{array}$ & $\begin{array}{r}59 \\
100\end{array}$ \\
\hline
\end{tabular}

Source: For new plants to relocators ratio, Lee, Choe, and Park (1985); for distance moved, Chun and Lee (1985).

as Tokyo. As production stages moved from the experimental to the routine or standardized, these industries were dispersed to hinterland locations or abroad. Product development and $R \& D$ require the information-rich environments found in large metropolitan areas, whereas efficient, standardized production requires the low land and labor costs found in smaller cities and less developed countries (Duranton and Puga 2001).

\section{Urbanization with Rapid Economic Growth}

For developing countries, studies suggest that urban concentration increases in the early stages of economic development as part of increasing regional disparities, and then decreases in later stages of development as part of decreasing regional disparities, or regional convergence (Williamson 1965; see also Parr 1985; El-Shakhs 1992;

\begin{tabular}{|c|c|c|c|}
\hline \multicolumn{2}{|l|}{$\begin{array}{l}\text { Inside Japan: } \\
\text { Share of total plants in } \\
\text { the major metropolitan areas }\end{array}$} & \multicolumn{2}{|c|}{$\begin{array}{l}\text { Abroad: } \\
\text { Share of total plants located abroad } \\
\text { in North America, European Union, } \\
\text { and newly industrialized countries, } \\
\text { as opposed to less developed countries. }\end{array}$} \\
\hline Headquarters and basic R\&D & $100(70)$ & & \\
\hline Developmental R\&D & $70(54)$ & Regional headquarters & $100(13)$ \\
\hline Trial production & $91(21)$ & R\&D & $91(32)$ \\
\hline Mass production & $43(333)$ & Production & $59(335)$ \\
\hline \multicolumn{4}{|c|}{$\begin{array}{l}\text { Note: Numbers in parentheses are the total number of plants in all locations in each } \\
\text { category (row). } \\
\text { Source: Fujita and Ishii (1994). }\end{array}$} \\
\hline
\end{tabular}


and Wheaton and Shishido 1981). Hansen (1990) suggests that in the early stages of development, when resources are scarce (especially infrastructure capital) it is impossible to invest enough in public infrastructure to support widespread urban agglomeration and a system of interconnected cities joined by paved highways, rail transit, and communication.

An efficient allocation of economic infrastructure requires concentration in just one or two cities (perhaps megacities) initially, conserving on spending that would go instead to linking cities or developing other cities. Such concentrated investment induces inmigration and industrialization of focal megacities and increases urban concentration. With accompanying economic growth, the country will develop some appropriate institutions and a pool of skilled technocrats. Eventually, the country will be able to invest in hinterland regions, allowing other major urban centers to develop as well as smaller and medium-size cities. That leads to urban deconcentration.

The concentration phase has been observed in many developing countries, but any subsequent deconcentration seems to be modest. There is a very strong cross-country relation between GDP per capita and measures of primacy and concentration: concentration increases up to mean (of log) GDP per capita worldwide and then decreases thereafter (box 4). The relation is significant and robust to specification. However, the magnitudes are tiny-roughly a 2.5 percent change in concentration as GDP per capita grows from low levels $(\$ 1,000)$ to the mean $(\$ 5,300)$.

This analysis shows few signs of population deconcentration. It does find exceptionally high concentration in certain regions, particularly Asia (excluding China), where primacy is about 20-30 percent higher than can be explained by typical measured economic forces. This is the Asian megacity phenomenon. This high concentration seems to stem from political and institutional forces that lead to a high centralization of resources, so that a high concentration of industry accompanies population concentration in these megacities.

Though significant population deconcentration may not be widespread, there appear to be strong forces encouraging industrial deconcentration from megacities, as costs of production escalate and living conditions deteriorate. Countries such as Korea that have encouraged industrial deconcentration have experienced enormous effects (box 5). Industrial deconcentration starts with deconcentration from the core primate city into its suburbs or satellite cities and then to the rest of the country. Deconcentration into the rest of the country enhances specialization across cities, as industrializing cities focus on a specific activity. Korea experienced the first stage of deconcentration into satellite cities before 1980 and the second into the hinterlands over the past 20 years.

Thailand and Indonesia seem to be experiencing some of the first stage of deconcentration of industry into satellite cities - starting in Thailand's case, certainly, from very high levels of concentration. Consider the Bangkok metropolitan area (see Isarankura 1990 and Lee 1988). Between 1970 and 1986 the urban population of 
Box 4. International Comparisons of Urban Concentration

Data for more than 85 countries for 1960, 1970, 1980, and 1990 show clear relationships between urban concentration measures and country characteristics (table 4). The first five columns examine primacy - the population in the largest city. The sixth column examines total population in cities over 750,000 .

\section{Basic Patterns}

The size of the largest city grows with national urbanization but much less than proportionally (an elasticity well below one). Urban primacy is weaker in larger countries, as economic resources are spread out with geographic size. As GDP per capita grows from low levels up to \$5,300 (approximate mean world GDP per capita in 1990), urban primacy increases. After that, it declines. Thus urban primacy is the same at $\$ 1,300$ as it is at $\$ 17,000$. But even at its peak, all else remaining unchanged, urban primacy is only 2 percent larger than at $\$ 1,300$ (or $\$ 17,000$ ). International trade also affects primate city size: a one-standard-deviation increase (48.8) in openness (imports plus exports as a percent of GDP) decreases primate city size by 27 percent.

A final major issue concerns regional differences, presumably capturing differences in broad institutional arrangements and attitudes. Regional dummy variables have little effect on other coefficients and captured unmeasured aspects of regions. Primacy is highest in Asia, in most formulations. This appears to capture the emerging Asian megacity phenomenon of development in countries such as Bangladesh, Indonesia, Japan, and Thailand, which is highly focused on one city. In the basic model, urban primacy also is significantly higher in Latin American and Sub-Saharan countries.

Centralization and Infrastructure Investments

Economic models suggest that centralization increases urban concentration. Centralization is hard to measure, but two effects are notable. First, when the primate city is the national capital, it is 25 percent or more larger than otherwise, suggesting resource centralization goes with political centralization. Second, the share of the central government in government consumption (nondefense spending), a crude summary measure of fiscal centralization, has strong, significant effects on primacy beyond the national capital effect on a limited sample covering 1980 and 1990 (column 3, table 4). A 1 standard deviation (0.31) increase in the central government's share increases primate city size by 9 percent. Government centralization appears to contribute strongly to urban concentration.

Another way to approach this question is to see what effect decentralized infrastructure investment (interregional transport and communications) has on urban deconcentration. Again, this is hard to measure. Data on the density of roads, telephone mainlines, and navigable waterways are available, but each set of data has problems. Telephone mainlines are highly correlated with GDP per capita and concentrated in urban areas, so effects are hard to disentangle. Road density is less correlated with GDP per capita, but the measure has no control for road quality or width. The density of navigable waterways (length of navigable waterways divided by land area) represents both geographic features (rivers and lakes) and investment in infrastructure (canals, dredging, rerouting, flood control). Navigable waterways are, however, a good measure of accessibility of hinterlands to the coast.

These problems aside, analysis shows that increased infrastructure density strongly reduces urban concentration (columns 4 and 5, table 4, with shifting sample sizes). After controlling for population and land area, waterways have enormous impacts—elasticities of five or six-opening up a country and reducing urban concentration. Road and telephone mainlines have negative but insignificant density effects, reducing urban concentration. These crude measures suggest that infrastructure investments help decentralize resources and shape urban deconcentration. 
Table 4. Determinants of Urban Primacy

\begin{tabular}{|c|c|c|c|c|c|c|}
\hline & \multicolumn{5}{|c|}{ Log population of largest city } & \multirow[b]{2}{*}{$(6)^{\mathrm{a}}$} \\
\hline & (1) & $(2)$ & (3) & $(4)$ & $(5)$ & \\
\hline Log national urban population & $\begin{array}{c}0.706^{*} \\
(0.022)\end{array}$ & $\begin{array}{c}0.707^{*} \\
(0.026)\end{array}$ & $\begin{array}{c}0.613^{*} \\
(0.038)\end{array}$ & $\begin{array}{c}0.755^{*} \\
(0.025)\end{array}$ & $\begin{array}{c}0.753^{*} \\
(0.044)\end{array}$ & $\begin{array}{c}0.894^{*} \\
(0.033)\end{array}$ \\
\hline Log national land area & $\begin{array}{c}-0.029 \\
(0.018)\end{array}$ & $\begin{array}{c}-0.037^{* *} \\
(0.020)\end{array}$ & $\begin{array}{c}0.021 \\
(0.033)\end{array}$ & $\begin{array}{c}-0.068^{*} \\
(0.019)\end{array}$ & $\begin{array}{c}-0.067 \\
(0.045)\end{array}$ & $\begin{array}{c}0.0028 \\
(0.024)\end{array}$ \\
\hline $\begin{array}{l}\text { Capital city dummy variable } \\
\text { ( } 1 \text { if city is the capital) }\end{array}$ & $\begin{array}{r}0.263^{*} \\
(0.064)\end{array}$ & $\begin{array}{r}0.263^{*} \\
(0.064)\end{array}$ & $\begin{array}{r}0.452^{*} \\
(0.096)\end{array}$ & $\begin{array}{r}0.380^{*} \\
(0.064)\end{array}$ & $\begin{array}{r}0.390^{*} \\
(0.089)\end{array}$ & \\
\hline Log per capita GDP & $\begin{array}{l}1.28^{*} \\
(0.324)\end{array}$ & $\begin{array}{c}0.910^{*} \\
(0.356)\end{array}$ & $\begin{array}{c}0.534 \\
(0.866)\end{array}$ & $\begin{array}{c}1.52^{*} \\
(0.374)\end{array}$ & $\begin{array}{c}2.39^{*} \\
(0.583)\end{array}$ & $\begin{array}{l}1.16^{*} \\
(0.433)\end{array}$ \\
\hline Log per capita GDP sq. & $\begin{array}{c}-0.078^{*} \\
(0.020)\end{array}$ & $\begin{array}{c}-0.053^{*} \\
(0.022)\end{array}$ & $\begin{array}{c}-0.030 \\
(0.052)\end{array}$ & $\begin{array}{c}-0.089^{*} \\
(0.023)\end{array}$ & $\begin{array}{c}-0.136^{*} \\
(0.036)\end{array}$ & $\begin{array}{c}-0.065^{*} \\
(0.027)\end{array}$ \\
\hline Open & $\begin{array}{r}-0.0056^{*} \\
(0.0011)\end{array}$ & $\begin{array}{c}-0.0056^{*} \\
(0.0011)\end{array}$ & $\begin{array}{c}-0.0092^{*} \\
(0.0016)\end{array}$ & $\begin{array}{c}-0.0049^{*} \\
(0.0011)\end{array}$ & $\begin{array}{c}-0.0060^{*} \\
(0.0014)\end{array}$ & $\begin{array}{r}-0.0065^{*} \\
(0.0013)\end{array}$ \\
\hline $\begin{array}{l}\text { Share of central government } \\
\text { in government consumption }\end{array}$ & & & $\begin{array}{c}0.306^{*} \\
(0.129)\end{array}$ & & & \\
\hline $\begin{array}{l}\text { Log of waterway density (ratio of length } \\
\text { of waterways to national land) }\end{array}$ & & & & $\begin{array}{c}-6.61^{*} \\
(1.02)\end{array}$ & $\begin{array}{r}-5.98^{*} \\
(1.24)\end{array}$ & \\
\hline $\begin{array}{l}\mathrm{Log} \text { of road density (ratio of lengh } \\
\text { of roads to national land) }\end{array}$ & & & & & $\begin{array}{l}-0.048 \\
(0.045)\end{array}$ & \\
\hline $\begin{array}{l}\text { Log of telephone main lines } \\
\quad \text { (per 1,000 people) }\end{array}$ & & & & & $\begin{array}{l}-0.022 \\
(0.047)\end{array}$ & \\
\hline Year 1970 & $\begin{array}{c}0.147^{*} \\
(0.060)\end{array}$ & $\begin{array}{l}0.143^{*} \\
(0.059)\end{array}$ & & $\begin{array}{c}0.117^{*} \\
(0.069)\end{array}$ & & $\begin{array}{c}0.089 \\
(0.074)\end{array}$ \\
\hline Year 1980 & $\begin{array}{c}0.329^{*} \\
(0.063)\end{array}$ & $\begin{array}{c}0.315^{*} \\
(0.064)\end{array}$ & $\begin{array}{l}0.131^{*} \\
(0.096)\end{array}$ & $\begin{array}{c}0.246^{*} \\
(0.062)\end{array}$ & $\begin{array}{l}0.152^{*} \\
0.071\end{array}$ & $\begin{array}{c}0.227^{*} \\
(0.076)\end{array}$ \\
\hline Year 1990 & $\begin{array}{c}0.379^{*} \\
(0.067)\end{array}$ & $\begin{array}{c}0.363^{*} \\
(0.070)\end{array}$ & $\begin{array}{l}0.166^{*} \\
(0.103)\end{array}$ & $\begin{array}{c}0.285^{*} \\
(0.068)\end{array}$ & $\begin{array}{c}0.217^{*} \\
(0.079)\end{array}$ & $\begin{array}{c}0.272^{*} \\
(0.079)\end{array}$ \\
\hline Sub-Saharan Africa & & $\begin{array}{c}0.084 \\
(0.098)\end{array}$ & $\begin{array}{c}-0.206 \\
(0.162)\end{array}$ & $\begin{array}{c}0.207^{*} \\
(0.098)\end{array}$ & $\begin{array}{c}0.311^{*} \\
(0.151)\end{array}$ & $\begin{array}{c}0.240^{*} \\
(0.113)\end{array}$ \\
\hline Latin America & & $\begin{array}{c}0.191^{*} \\
(0.073)\end{array}$ & $\begin{array}{c}-0.085 \\
(0.112)\end{array}$ & $\begin{array}{l}0.120^{* *} \\
(0.069)\end{array}$ & $\begin{array}{c}0.065 \\
(0.107)\end{array}$ & $\begin{array}{c}0.194^{*} \\
(0.081)\end{array}$ \\
\hline Asia & & $\begin{array}{c}0.221^{*} \\
(0.082)\end{array}$ & $\begin{array}{c}0.302^{*} \\
(0.112)\end{array}$ & $\begin{array}{c}0.226^{*} \\
(0.071)\end{array}$ & $\begin{array}{c}0.207^{*} \\
(0.091)\end{array}$ & $\begin{array}{c}0.347^{*} \\
(0.084)\end{array}$ \\
\hline Middle East and North Africa & & $\begin{array}{c}0.207^{*} \\
(0.081)\end{array}$ & $\begin{array}{c}0.240^{*} \\
(0.120)\end{array}$ & $\begin{array}{c}0.058 \\
(0.080)\end{array}$ & $\begin{array}{c}0.024 \\
(0.124)\end{array}$ & $\begin{array}{c}0.211^{*} \\
(0.087)\end{array}$ \\
\hline Constant & -3.71 & -2.07 & 0.708 & -4.97 & -8.67 & -5.05 \\
\hline Number of observations & 320 & 320 & 127 & 286 & 147 & 237 \\
\hline Adjusted $R^{2}$ & 0.895 & 0.899 & 0.889 & 0.919 & 0.910 & 0.922 \\
\hline $\begin{array}{l}\text { "Significant at the } 5 \text { percent level. } \\
{ }^{* *} \text { Significant at the } 10 \text { percent level. } \\
\text { Note: Numbers in parentheses are stand } \\
\text { aThe dependent variable is population in } \\
\text { Source: Author's calculations based on }\end{array}$ & $\begin{array}{l}\text { dard errors. } \\
\text { n cities over } \\
\text { data from the }\end{array}$ & $\begin{array}{l}750,000 . \\
\text { e United N }\end{array}$ & ns and & rld Bank. & & \\
\hline
\end{tabular}


Box 5. Deconcentration in the Republic of Korea

The urban primacy of Seoul peaked in the early 1970s and declined thereafter (table 5), even though Seoul's share of national population continued to rise with rapid national urbanization. Seoul's share of the population of the surrounding Kyonggi Province has not changed much in 25 years. What is dramatic is Seoul's loss of manufacturing employment. With rising suburbanization, Seoul's share declined from 76 percent in 1970 to 45 percent in 1983 and 30 percent in 1993 (table 6), reflecting both natural market forces as firms left high wages and rents in Seoul for nearby cities and policies encouraging suburbanization.

However, a key aspect of deconcentration in Korea has been the spread of industry throughout the country following the massive intercity infrastructure investments of the late 1970s and early 1980s and the economic and political liberalization of the 1980s. The employment shares of Seoul and the other two major metropolitan areas of Pusan and Taegu declined in the 1980s, while satellite cities (over 50,000 urban residents in 1983) in the provinces of Kyonggi and South and North Kyongsang surrounding the three major metropolitan areas held constant (table 7). Where did industry go? Mostly to rural areas and cities in other provinces.

This deconcentration occurred in all manufacturing industries and was comprehensive. Korea's 10 major manufacturing industries (over 130,000 employees nationally in 1993) are traditional food processing, textile, apparel, nonmetallic minerals, modern chemicals, rubber, fabricated metal, motor vehicles, machinery, and communications equipment. For each of the 10 industries, Lee (1998) calculates an Ellison and Glaeser (1997) or normalized Hirschman-Herfindahl index of the degree of spatial concentration across provinces and 50 cities in 1983. The index for industry $j$ is

$$
\begin{gathered}
n \\
G_{j}=\sum\left(S_{i j}-S_{i}\right)^{2} \\
i=1
\end{gathered}
$$

where $S_{i j}$ is region i's share of total national employment in industry $j$, and $S_{i}$ is region i's share of national manufacturing employment. With perfect deconcentration, $G_{j}=0$, because each region's share of industry j's employment mimics its share of national manufacturing employment. With perfect concentration $G_{j}$ exceeds one, where one region has all of industry j's employment $\left(S_{i j}=1\right.$ for that region) and little of national employment.

Across the nine provinces from 1983 to 1993, G drops dramatically for all six modern industriesby 95 percent or more in most cases and a minimum drop of 42 percent. Nationally, modern industries deconcentrated rapidly throughout the country. For traditional industries, G changes only modestly. Traditional industries, especially food processing and nonmetallic minerals, were already deconcentrated and remained that way.

In contrast to deconcentration across the nine provinces, concentration increases across the 50 cities for all industries except textiles, for which concentration remains unchanged. The rise is dramatic for some modern industries, such as chemicals and rubber, and in most cases it is strong. Is this a paradoxdeclining regional concentration in modern manufacturing industries, but rising urban concentration in the same industries? Not at all. Cities specialize in production. So with liberalization, infrastructure investments, and decentralization inducements, there is national deconcentration of industry spatially. However, these same policy changes allow cities to become more specialized as they industrialize. Korea is well on the path to having a mature system of cities. 


\begin{tabular}{lrrrr}
\hline Table 5. Metropolitan Seoul's Share of Population (percent) \\
\hline \multicolumn{1}{l}{1960} & 1970 & 1980 & 1990 \\
\hline National urban population & 34 & 41 & 38 & 33 \\
National population & 9 & 17 & 22 & 25 \\
\hline \multicolumn{1}{l}{ Source: Lee (1997). } & & & & \\
\hline
\end{tabular}

the core Bangkok metropolitan area grew 4.3 percent a year, while key satellite suburban areas (Samut Prakarn, Nonthaburi, and Pathum Thani) grew 5.7-8.0 percent a year. Manufacturing employment grew at average annual rates of 8.2-12.6 percent in all five suburban areas defined by Isarankura (1990), but at 7.2 percent in the Bangkok area, which was increasingly focusing on service production. Lee (1988) reports that in 1982 the start-up rate for new manufacturing establishments was 7.4 percent in Bangkok and 8.9-16.9 percent in the suburban areas. Despite these differentials strongly favoring suburban areas, the absolute population growth rate in the core metropolitan area remains very high.

Although industry may eventually deconcentrate from primate cities, deconcentration may be delayed too long for many developing countries, which appear to undergo strong initial sustained increases in population concentration. Are there compelling reasons to believe that this concentration is excessive? If so, what are the costs of excessive concentration?

\section{Is Concentration Excessive?}

Many economic policies inadvertently promote inefficient concentration, delaying the provision of appropriate infrastructure and services outside the central city until long after it is efficient to do so. Urban development in the primate cities may be significantly underpriced, considering that air pollution, noise pollution, contamination from waste disposal, and traffic congestion remain unpriced or underpriced externalities. These externalities are much lower in small cities than in large cities, so that they are relatively more underpriced in big cities, which confers an advan-

Table 6. Metropolitan Seoul's Share of Population and Manufacturing in Kyonggi Province (percent)

\begin{tabular}{lcccc}
\hline & 1970 & 1980 & 1983 & 1993 \\
\hline Population & 62 & 63 & 67 & 61 \\
Manufacturing & 76 & 61 & 45 & 30 \\
\hline \multicolumn{5}{l}{ Note: Data excludes Inchon metropolitan area. } \\
Source: Lee (1997). \\
\hline
\end{tabular}




\begin{tabular}{lcc}
\hline $\begin{array}{l}\text { Table 7. Cities' Share of National Manufacturing } \\
\text { Employment (percent) }\end{array}$ & 1983 & 1993 \\
\hline Seoul & 21 & 14 \\
Pusan and Taegu & 23 & 14 \\
Satellite metropolitan areas & 30 & 30 \\
Other cities, other rural areas & 12 & 17 \\
Rural areas of satellite city provinces & 14 & 25 \\
\hline \multicolumn{3}{l}{ Source: Lee (1997). } \\
\end{tabular}

tage for large cities in attracting population that is socially costly (Tolley 1979). The advantage is accentuated in megacities, where negative externalities are particularly severe.

In some countries, export and import licensing and financial markets are centralized. People seeking licenses and loans need to locate in the primate city so that they can apply political, social, and financial resources to the pursuit of their applications. In Korea initial deconcentration of industry from Seoul to industrial parks in satellite cities in the 1970s was impeded by the bureaucratic bottlenecks in capital and international markets. Plants needed to be within half to three-quarters of an hour commuting time from downtown Seoul (Kwon 1985; Chun and Lee 1988) to make access feasible. These bottlenecks were eased in the early 1980s. In Indonesia, even after liberalization, financial markets for large loans remain highly centralized. Prospective borrowers are required to apply in person in Jakarta. Similar impediments surround export-import permissions, nonmarket allocations of raw materials, location permits, and monopoly licensing (Henderson and Kuncoro 1996).

Why are licensing procedures, financial markets, and allocation mechanisms more centralized in some countries? One reason is rents. If the authorities seek rents on licenses, permits, or loans, then a central authority would not wish to see decentralization, which would create potential competitors for the rents. Another reason is the large city bias of many policies, which are designed to favor the centralized development of large cities at the expense of more rural hinterlands. O (1993) and others illustrate this for China.

\section{Costs of Excessive Deconcentration}

What are the costs of excessive urban concentration? Strong and robust econometric evidence in Henderson (1999) suggests that excessive concentration significantly reduces economic growth rates. Growth losses in countries with excessive primacy may be as great as those resulting from significantly deficient human and physical capital investment. Why? Because wage, land, and infrastructure costs escalate with 
megacity size relative to scale benefits for standardized products, making it more difficult to attract foreign investment and to remain competitive in world markets. Also, excessive concentration leads to degradation of the quality of life as population concentration rises. Problems with congestion, contamination of ground water, gastrointestinal and infectious diseases, and poor air quality are severe in many cities (see box 6 on Jakarta). The quality of life and public service issues are exacerbated by a lack of technical expertise in planning and managing megacities. As environmental quality in megacities declines, infrastructure investment becomes increasingly focused on trying to alleviate the effects of these unpriced negative externalities.

\section{Influencing Deconcentration}

As discussed, better pricing of goods and negative externalities in large metropolitan areas and liberalization and decentralization of financial markets, licensing, and permits can help countries avoid excessive concentration. So can intercity infrastructure investments, economic openness, and appropriate government structure and institutions, the subject of this section.

\section{Infrastructure Investment}

A key condition for urban deconcentration seems to be investment in modern intercity transport and communications. Conceptually the point is straightforward. Manufacturers cannot move from the main city (typically a port city) of a country to hinterland locations unless they are linked to the port and national and international markets by good transport and communication. Containerization and ready movement of freight are essential for purchasing inputs and getting products to market at reasonable delivered prices in a timely fashion. In a globalized world of just-in-time production and inventories slashed to reduce costs, reliable transport that is reasonably fast and cheap is essential. Good communications are also critical for interaction with buyers, suppliers, parent firms, and government regulators.

What is the evidence? As already noted, urban concentration is negatively related to crude measures of infrastructure-navigable waterways (requiring interconnecting canals, dredging, and maintenance) and road and telephone density (see box 4). That evidence is supported by econometric modeling using cross-country panel data (Henderson 1999). For example, with the development of major toll roads east and west from Jakarta into Botabek, Bekasi, and Tangerang (known collectively as Jabotabek), metropolitan (DKI) Jakarta's share of Jabotabek's formal sector manufacturing employment fell from 57 percent in 1986 to 44 percent in 1991, and its share of start-ups dropped dramatically, especially for the corporate portion of the formal sector (Henderson, Kuncoro, and Nasution 1996). ${ }^{2}$ Korea's 
Box 6. Unpriced Externalities of Mega Cities: The Example of Jabotbek

Sewer and Water in DKI Jakarta

Only 2.1 percent of the population of Jakarta in 1990 was served by an off-site sewerage connection, such as a conventional trunk sewer. Most of the rest relied on pit latrines and septic systems, which are unsuitable for high-density areas. Septic system failures are common, resulting in soil and water contamination. The sewerage problem is compounded by the use of groundwater by half the population (only 10 percent of households had piped water in 1992, and 20 percent purchased water from vendors; World Bank 1993).

These problems were most intense in the low-income areas of Jakarta Utara (North Jakarta) around the coastal port area, where households have no trunk sewers or piped water connections. Overpumping of groundwater has caused heavy and growing salination; 47 percent of low-income residents buy water from vendors (just 6 percent of high-income residents do). Disease incidence was higher in Jakarta Utara as well. In 1986-88 the incidence of gastroenteritis was 37.4 per 1,000 residents; of typhoid, 8.6; and of dysentery, 11.5, compared with 23.7, 3.0, and 5.2 for the rest of DKI Jakarta.

These high health costs have arisen because of unpriced externalities-both sewage disposal and groundwater pumping. Not only older neighborhoods are affected. New developments are poorly served as well because of poor land use planning and development policies, as the land development process in the suburban Botabek area shows.

\section{Land Development in Botabek}

Three national ministries control land use planning in Indonesia-Bappenas (planning), Public Works, and Home Affairs-but without any clear delineation of responsibilities. Local officials issue the land development permits. Aksoro (1994) argues that local officials in rural suburbanizing areas are uninformed about land use, often even lacking maps showing current use. "Planning" is simply a cataloging of evolving land use as dictated by private developers. In a typical scenario, Public Works builds an arterial highway from Jakarta into the rural hinterland with little consultation with local (rural) officials. Large-scale, sophisticated developers approach local officials for development permits. Negotiated developer permits give each developer complete monopsony power for three years to buy land in the designated area for future development.

The most important failure is the lack of required land improvements. Developers "strip-develop" in shallow, unconnected pockets along arterial roads, to avoid having to invest in side and feeder roads. That creates urban sprawl, with long strips of development along highways, requiring even more highway construction to encourage suburbanization. Proper planning would require deep-pocket development, with proper side and feeder roads linking developments to one another. Additionally, developers are not required to invest in proper infrastructure. Requirements for piped water connections are not enforced, so that groundwater pumping (with unauthorized unmetered deep wells) occurs, contributing to metropolitan Jakarta's water problems. Installation of sewage lines and connections is incomplete. Even where lines do exist, untreated sewage simply flows into canals and unauthorized ponds.

All these negative externalities of population growth in metropolitan Jakarta are unpriced. Because these externalities are much worse in Jakarta than in other cities, the lack of pricing or other regulation means that immigration into Jakarta is underpriced, or subsidized, relative to its true cost and relative to its cost in other cities. That encourages overpopulation. Simply saying "price the externalities" is not going to change the process. Institutional change is also required. 
rapid industrial deconcentration (see box 5) can be directly linked to its heavy nationwide investment in telecommunications since the late 1970s. From enormous disparities in the early 1970 s, telecommunications capital stock per capita converged to nearly regional equality by the early 1990s, leading the deconcentration process.

\section{Globalization and Openness}

Simple cross-country regressions, as well as more complex time series regressions, suggest a strong negative correlation between international trade and urban concentration. A one standard deviation increase in openness is associated with a 25 percent decline in primacy and similar declines in other measures of concentration (see box 4). The new economic geography models predict that a country's exposure to trade may encourage hinterland development (Krugman and Venables 1995; Krugman and Livas 1996; Puga and Venables 1996).

The link is not obvious. In a country with a dominant primate city and poor intercity infrastructure, greater trade associated with industrialization could promote enhanced primacy. So, if a Nike or Sony wants to locate assembly of standardized products or production of low-tech components in a cheap-labor country, it would initially focus on the primate, coastal city if the hinterlands are cut off by poor infrastructure. However, the relatively high land, labor, and congestion costs of operating in an increasingly oversized megacity would provide strong incentives to deconcentrate. The new economic geography literature suggests that products destined for international markets are less tied to focal points of national population and local demand and are freer to seek hinterland locations. If local cost conditions deteriorate, the threat of international producers moving to other countries may spur domestic infrastructure investments to permit deconcentration. Exporters facing stiff international competition also may be more eager to move to cheaper hinterland locations.

The deconcentration of manufacturing from metropolitan Jakarta to its hinterland region was spurred in part by foreign producers. In 1989, firms with more than 50 percent foreign ownership accounted for only about 9 percent of manufacturing employment in medium-size and large plants in both the Bobatek suburb of Jakarta and DKI Jakarta. By 1993 these firms accounted for 27 percent of such employment in the Botabek suburb but only 14 percent in DKI Jakarta, despite the development of free export zones in DKI Jakarta.

\section{Role of Government Structure and Institutions}

Government structure and institutions may play a key role in determining the deconcentration of urban activity. Many economists believe that decentralized governments and institutions lead to greater deconcentration. The evidence in Henderson (1999) suggests significant but surprisingly small effects on deconcentration, as coun- 
tries shift to decentralized governmental structures. However, the cross-sectional evidence on historical institutions is strong. Henderson (1988) finds, other things being equal, that a federal system of government reduces a common HirschmanHerfindahl index of urban concentration by more than 40 percent. Ades and Glaeser (1995) find a similar reduction in a primacy index for a similar switch in government regime (see also Petrakos and Brado 1989).

The concentration regressions in box 4 find that the mere fact that the primate city is the national capital increases its size by more than 25 percent, indicating that resource centralization is not uncorrelated with the seat of power. A crude measure of the share of the central government in overall government consumption has a very strong positive effect on concentration, over and above the national capital effect. Contrast the high urban concentration and high government decentralization in Bangladesh, Indonesia, or Thailand, for example, with the low urban concentration and low government centralization in China or India.

Economists look to the Tiebout (1956) model to explain the relation between urban concentration and government centralization. This model calls for local fiscal autonomy in the provision of services that are local in nature. The key to a successful local political process is local participation in political processes (local democratic voting outside the influence of the central government and reasonably unconstrained by national-level party officials), local determination of local taxes and revenues at the margin, and local determination of expenditure levels.

Local fiscal autonomy is viewed as efficient for two interrelated reasons. First, each locality's industrial needs and tastes for services differ, and there is asymmetric information - the national government will be unaware of specific local needs and tastes, which can be better ascertained through local political processes. If localities pay for public services, at least at the margin, they will make expenditure decisions based on (true) marginal costs, so allocations may be more efficient. Second, unitary governments may favor the national capital, creating a primate city bias in public services, infrastructure investments, and allocations from capital and import-export markets. This favoritism draws in immigrants. A decentralized situation creates and empowers hinterland cities and local governments to compete freely for industry and residents with the national capital, through tailored investments in infrastructure and public service offerings.

A key element in decentralization is revenue sources for the operating and capital accounts for autonomous local (or state) governments. Cities such as Bombay and Karachi testify to the fact that cities can operate with almost entirely local revenues, despite the common impression that local governments in low-income countries cannot raise sufficient local revenues (Bahl and Linn 1992:table 13.1). But financing local infrastructure investment and funding the capital account remain thorny issues. Efficient levels of long-term (intergenerational) investment cannot readily be financed from current taxes; they need to be financed over the long term, generally 
by floating bonds and establishing sinking funds to pay them off. That requires a sophisticated capital market to monitor local government creditworthiness, good communications and information gathering, and probably an adequate level of economic development.

Low-income and high-income countries alike also rely heavily on intergovernmental transfers. India, for example, allocates funds to states and then to localities from the national plan, on a 30 percent/70 percent grant-to-loan ratio, using a formula based on population, income, special circumstances, and so on. Several problems typically attend this system. The loans are often forgiven, so the loan costs to localities are uncertain. Funding is forced, automatic, and unresponsive to local needs in the level and composition of expenditures. Funding is also inadequate. For large metropolitan areas in India and Pakistan, inadequate funding is addressed by creating metropolitan development authorities, which can float bonds, thereby having some control over financing levels at the margin. Indonesia has national development funds for which localities can apply. These are supposed to be revolving funds (new loans are financed out of repayments), but, as in India, loans are not repaid.

\section{Conclusion}

The rapid urbanization in many developing countries over the past half century seems to have been accompanied by excessively high levels of concentration of the urban population in very large cities. This pattern is seen most prominently in the recent development of Asian megacities.

Some degree of urban concentration may be desirable initially to reduce inter- and intraregional infrastructure expenditures. But in a mature system of cities, standardized manufacturing production tends to be deconcentrated into smaller and mediumsize metropolitan areas, whereas production in large metropolitan areas focuses on services, R\&D, and nonstandardized manufacturing. The problem in today's developing countries is that there appear to be strong biases toward excessive concentration.

Such concentration reflects several forces. Externalities of congestion and pollution are relatively underpriced in megacities relative to smaller cities, encouraging overpopulation of larger cities. Rent seeking and urban bias by central government bureaucrats result in the centralization, often in capital cities, of capital markets and licensing for exports, imports, plant production, and material allocations, forcing a centralized location of production. Finally, infrastructure investments and public services provision outside of main cities and interregional linkages seem to remain at too low levels for too long.

The costs of excessive concentration stem from the large sizes of megacities and underdeveloped institutions and human resources for urban planning and manage- 
ment. These costs include traffic accidents, health costs from exposure to high levels of air and water pollution, and time lost to inordinately long commutes.

Alleviating excessively high urban concentration requires investments in interregional transport and telecommunications to facilitate deconcentration of industry. It also requires fiscal deconcentration, so that interior cities can raise the fiscal resources and provide the services needed to compete with primate cities for industry and population.

\section{Notes}

Vernon Henderson is Eastman Professor of Political Economy at Brown University. Vernon Henderson can be reached via e-mail at Vernon_Henderson@brown.edu.

1. The correlation is from a regression of percent urbanized on GDP per capita pooling cross-country data for 1960, 1970, 1980, and 1990 for a total of 508 observations. Fixed-effects formulations also show a similar critical role of GDP per capita.

2. But there is now spatial balance overall in Jabotabek. Plant-level wage regressions for 1993 indicate that wages in Bobatek suburbs in medium-size and large plants for production workers are 21 percent lower than in central Jakarta, controlling for industrial composition, foreign ownership, and plant legal organization. Productivity regressions indicate that plant productivity (controlling for industry, capital-to-labor ratio, and foreign ownership) is 14 percent lower in Botabek. For a capital share coefficient of 0.35 that represents a perfect balance on average, where the impact of the productivity loss is just offset by the reduction in labor costs. Assume a constant cost of capital with capital rental equal to its value of marginal product in a Cobb-Douglas production function with an estimated capital share of 0.35 and a labor share of 0.65 . Then, if producers are in equilibrium, the ratio of wages in central Jakarta to those in Botabek (» 1.208) should equal the productivity gap $(1.14)^{1 / 0.65}$ or 1.22.

\section{References}

Abdel-Rahman, H., and M. Fujita. 1990. "Product Varieties, Marshallian Externalities and City Sizes." Journal of Regional Science 2:165-83.

Ades, A. F., and E. L. Glaeser. 1995. “Trade and Circuses: Explaining Urban Grants.” Quarterly Journal of Economics 110:195-227.

Aksoro, L. W. 1994. "The Effects of the Location Permit in Urban Land Markets.” Master's thesis, Massachusetts Institute of Technology, Cambridge, Mass.

Bahl, R. W., and J. F. Linn. 1992. Urban Public Finance in Developing Countries. New York: Oxford University Press.

Banerjee, N. 1985. Women Workers in the Unorganized Sector: The Calcutta Experience. Hyderabad: Sangain Books.

Becker, C. M., J. G. Williamson, and E. S. Mills. 1992. Indian Urbanization and Economic Growth Since 1960. Baltimore, Md.: Johns Hopkins University Press.

Becker, R., and J. V. Henderson. 2000. “Intra Industry Specialization and Urban Development.” In J. M. Huriot and J. F. Thisse, eds., The Economics of Cities. Cambridge: Cambridge University Press.

Bergsman J., P. Greenston, and R. Healy. 1972. "The Agglomeration Process in Urban Growth.” Urban Studies 9:263-88. 
Black, D., and Henderson, J. V. 1999. "Theory of Urban Growth.” Journal of Political Economy 107:252-84.

Black, D., and J. V. Henderson. 1998. "Urban Evolution in the USA.” Brown University Working Paper 98-21, Providence, R.I.

Caplin, A., and J. Leahy. 1998. “Miracle on Sixth Avenue.” Economic Journal 108:62-74.

Chun, D. H., and K. S. Lee. 1985. "Changing Location Patterns in Population and Employment in the Seoul Region.” Report No. UDD-65, World Bank, Washington, D.C.

Dixit, A., and J. E. Stiglitz. 1977. "Monopolistic Competition and Optimum Product Diversity.” American Economic Review 67:297-308.

Duranton, G., and D. Puga. 2001. “Nursery Cities.” American Economic Review 91:1454-77.

Eaton, J., and Z. Eckstein. 1997. "Cities and Growth: Theory and Evidence from France and Japan." Regional Science and Urban Economics 27:443-74.

Ellison, G., and E. Glaeser. 1997. "Geographic Concentration in US Manufacturing Industries: A Dartboard Approach." Journal of Political Economy 105:889-927.

El-Shakhs, S. 1992. "Development, Primacy and Systems of Cities.” Journal of Developing Areas 7:11-30.

Fujita, M., and T. Ishii. 1994. "Global Location Behavior and Organizational Dynamics of Japanese Electronic Firms and Their Impact on Regional Economics.” Paper prepared for Prince Bertil Symposium on the Dynamic Firm, Stockholm, June.

Fujita, M., and M. Ogawa. 1982. "Multiple Equilibria and Structural Transition of Non-Monocentric Urban Configurations.” Regional Science and Urban Economics 12:161-96.

Glaeser, E., H. D. Kallal, J. Scheinkman, and A. Shleifer. 1992. "Growth in Cities." Journal of Political Economy 100:1126-52.

Hansen, N. 1990. "Impacts of Small and Intermediate-Sized Cities on Population Distribution: Issues and Responses.” Regional Development Dialogue 11(spring):60-76.

Helsley, R., and W. Strange. 1990. "Matching and Agglomeration Economies in a System of Cities." Regional Science and Urban Economics 20:189-212.

Henderson, J. V. 1988. Urban Development: Theory, Fact and Illusion. New York: Oxford University Press.

_. 1999. "How Urban Concentration Affects Economic Growth.” Policy Research Working Paper 2326, World Bank, Infrastructure and Environment, Development Research Group, Washington, D.C.

Henderson, J. V., and A. Kuncoro. 1996. "Industrial Centralization in Indonesia.” World Bank Economic Review 10:513-40.

Henderson, J. V., A. Kuncoro, and M. Turner. 1995. "Industrial Development of Cities.” Journal of Political Economy 103:1067-90.

Henderson, J. V., A. Kuncoro, and P. Nasution. 1996. "Dynamic Development in Jabotabek.” Indonesian Bulletin of Economic Studies 32:71-96.

Henderson, J. V., T. Lee, J.-Y. Lee. 2001. "Scale Externalities in Korea.” Journal of Urban Economics 49:479-504.

Holmes, T. 1997. "How Industries Migrate When Agglomeration Economies Are Important." Journal of Urban Economics 45:240-63.

Hoover, E.M. 1948. The Location of Economic Activity. New York: McGraw-Hill.

Isarankura, W. 1990. "Emerging Urban-Regional Linkages: The Bangkok Metropolitan Region.” Regional Development Dialogue 11(2):56-82.

Jacobs, J. 1969. The Economy of Cities. New York: Random House.

Krugman, P. 1991. "Increasing Returns and Economic Geography." Journal of Political Economy 99:483-94.

Vernon Henderson 
Krugman, P., and R. E. Livas. 1996. "Trade Policy and the Third World Metropolis.” Journal of Development Economies 49:137-50.

Krugman, P., and A. Venables. 1995. "Globalization and the Inequality of Nations.” Quarterly Journal of Economics 110:857-80.

Kwon, W. G. 1985. "Issues and Problems in Planning and Implementing Industrial Location Policies in Korea.” World Bank Discussion Paper, Washington, D.C.

Lee, K. S. 1988. "Infrastructure Constraints on Industrial Growth in Thailand.” World Bank, Industry and Urban Development Working Paper 88-2, Washington, D.C.

Lee, K. S., S. C. Choe, and K. H. Park. 1995. "Determinants of Locational Choice of Manufacturing Firms in the Seoul Region.” Report No. UDD-85, World Bank, Washington, D.C.

Lee, T. C. 1997. "Industry Deconcentration and Regional Specialization in Korean Manufacturing." Ph.D. diss., Brown University, Department of Economics, Providence, R.I.

Marshall, Alfred. 1890. Principles of Economics. London: Macmillan.

Mukherjee, R. 1990. "Conditions of Labor in the Small Scale and Unorganized Sectors in Calcutta and Its Neighborhood.” WEP 2-43/WP.36, International Labour Office, Geneva.

Muth, R. 1969. Cities and Housing. Chicago: University of Chicago Press.

Nakamura, R. 1985. “Agglomeration Economies in Manufacturing.” Journal of Urban Economics $17: 108-24$.

O, Jean C. 1993. "Reform and Urban Bias in China.” Journal of Development Studies 29(4):129-48.

Parr, J. B. 1985. “A Note on the Size Distribution of Cities over Time.” Journal of Urban Economics 18(1):99-112.

Petrakos, G., and J. C. Brada. 1989. "Metropolitan Concentration in Developing Countries.” Kyklos 42:557-78.

Puga, D., and A. Venables. 1996. "The Spread of Industry.” Journal of Japanese and International Economies 10:440-64.

Rauch, J. 1993. "Productivity Gains from Geographic Concentration of Human Capital.” Journal of Urban Economics 34:380-400.

Richardson, H. 1987. “The Costs of Urbanization: A Four Country Comparison.” Economic Development and Cultural Change 33:561-80.

Romer, P. M. 1986. "Increasing Returns and Long Run Growth.” Journal of Political Economy 94:100237.

Rousseau, M. P. 1995. “Les Parisiens sont surproductifs.” Études Foncières 68:13-18.

Tiebout, C. 1956. “A Pure Theory of Local Expenditures.” Journal of Political Economy 64:416-24.

Thomas, V. 1980. "Spatial Differences in the Cost of Living." Journal of Urban Economics 8:108-22.

Tolley, G. 1979. Urban Growth in a Market Economy. New York: Academic Press.

Wheaton, W., and H. Shishido. 1981. "Urban Concentration, Agglomeration Economies and the Level of Economic Development." Economic Development and Cultural Change 30:17-30.

Williamson, J. 1965. "Regional Inequality and the Process of National Development." Economic Development and Cultural Change 13:3-45.

World Bank. 1993. "Indonesia: Urban Infrastructure Services.” World Bank, East Asia and Pacific Water and Infrastructure Division, Washington, D.C. 